\title{
A Review on Male Sterility-Concepts and Utilization in Vegetable Crops
}

\author{
Sunidhi Mishra* and Versha Kumari \\ Department of Vegetable Science, Indira Gandhi Krishi Vishwavidyalaya, Raipur (C.G), India \\ *Corresponding author
}

\section{A B S T R A C T}

\section{Key words \\ Male sterility, Vegetable crops, Hybrid seed production, Marker genes}

Article Info

Accepted:

26 January 2018

Available Online:

10 February 2018
Male sterility is characterized by non-functional pollen grains, while female gametes function normally. It occurs in nature sporadically, perhaps due to mutation. The phenomenon of male sterility is of great significance to produce cost effective hybrid seeds. Onion crop provides one of the rare examples of very early recognition of male sterility (Jones and Emsweller, 1936), its inheritance and use in hybrid seed production (Jones and Clarke, 1943). Since then male sterility has been reported in fairly large number of crops including vegetables. These male sterility plants were either isolated in natural populations or were artificially induced through mutagenesis (Kaul, 1988). Recently, male sterility systems generated through genetic engineering (Williams et al., 1997) and protoplast fusion (Pelletier et al., 1995) have been also developed.

\section{Classification of male sterility}

Different kinds of male sterility systems have been reported in vegetable crops which eliminate the laborious and expensive operation of emasculation. The male sterile plants are spontaneous mutants, among which some are temperature sensitive.

Out of the four types of male sterility encountered in crops, i.e., Genetic (Pollen sterility), stamenless (Starninal sterility), closed anther (functional sterility) and longistyly (positional sterility), the closed anther type is considered as the most useful as it consists of viable pollen grains and hence selfing is possible to easily maintain the male sterility and thus the obtained progenies are all male sterile. The other mutants are required to be maintained in heterozygous condition and in the crossing block maximum $50 \%$ male sterile plants can be obtained through backcrossing and that too in a scattered condition (Chaudhari, 1992 and Hazra and Som, 1999).

\section{Steps in utilization of male sterility}

Male sterility is manifested in several vegetable crops. It may be genic (GMS), cytoplasmic (CMS) or interaction of nuclear gene and cytoplasm (CGMS). Utilization of male sterility involves following steps:

Identification of male sterility, Transfer of male sterility character into the desirable 
variety by repeated back crossing which will be used as female parent in hybrid seed production,

Perpetuation of male sterile lines by developing maintainer line and

Development of hybrid seeds in open or by hand pollination.

The male sterile (female) lines are grown with male fertile (pollinator or male) lines in proportions of 4-6: 1 in isolation for the production of hybrid seeds.

\section{Genetic male - sterility}

Genetic male sterility is controlled by the gene(s) from the nuclear compartment. This male sterility is generally controlled by a single recessive gene (ms) and has been reported in tomato, brinjal, chilli, sweet pepper, pea, lima bean, pumpkin, squash, water melon, muskmelon, ridge gourd, cucumber, cauliflower, cabbage, broccoli and brussels sprout.

All the transgenic male sterile lines developed till date are GMS, since they have been developed through transformation of male sterility causing gene construct(s) inside the nuclear genome. Certain mutants, which although produce functional pollen, fail to self-fertilize, either due to non-dehiscence of pollen or their special flower morphology. These mutants are often termed as functionally sterile, for example genotypes with exerted stigma in tomato (Georgiev, 1991), brinjal and several other vegetables (Kaul, 1988).

\section{Environment Sensitive Genetic Male sterility (EGMS)}

Certain genetic male sterile lines are conditional mutants i.e., male sterility is expressed only in certain set or range of environmental conditions, in absence of which the male sterile plants turn into male fertile. After determination of critical environment (usually temperature or photoperiod) for sterility and fertility expression, such GMS mutants are classified as Temperature sensitive Genic Male Sterile (TGMS) lines or Photoperiod sensitive Genic Male Sterile (TGMS) lines. EGMS lines (mostly temperature sensitive) have been reported in several vegetable crops like cabbage, Brussels sprout, broccoli, peppers (chilli and sweet pepper), tomato and carrot. A majority of these, however, were previously identified as normal genic male sterile lines. (Kumar et al., 2000)

Due to the problem of instability, EGMS lines were considered to be of very less practical value initially, but presently they represent most efficient system for hybrid seed production. However, from practical viewpoint, it is necessary to identify critical temperature or photoperiod for the fertility/sterility expression in temperature and photoperiod sensitive genetic male sterility, respectively.

\section{Utilization of GMS and EGMS}

First step in the utilization of GMS system is seed multiplication of male sterile line i.e., Maintenance of GMS, which is not possible through selfing or sibing, since pollen is either not viable or not produced. The genetic male sterility is governed by monogenic recessive ( $m s m s$ ) gene and is maintained by crossing it with heterozygous maintainer line (Msms) which is isogenic to male sterile line for the recessive male sterile $(m s)$ gene. The progenies obtained will contain both male sterile (msms) and male fertile (Msms) plants in the ratio of $1: 1$. Thus, $50 \%$ of the progenies (heterozygous and fertile) must be rogued out regularly before flowering, which otherwise may contaminate the hybrid seed set on male 
sterile female parent. The need to remove the male fertile plants from female parent population is tedious and comprises the most problematic part of hybrid seed production through use of Genetic male sterility system. In general, male sterile plants are morphologically not distinguishable from the sister fertile plants, except in few cases, where male sterile flower size is smaller than that of fertile flowers e.g. tomato (Sawhney, 1997) and chilli. The efficiency of this system can be increased by using closely linked recessive phenotypic marker gene so that the male sterile plants can be detected prior to anthesis, preferably at seedling stage. Thus, labour and time required for identification and removal of fertile plants in hybrid seed production field can be avoided.

\section{Advantages of EGMS}

Hybrid seed production through EGMS line is more attractive because of the ease in seed multiplication of male sterile line. Seeds of EGMS line can be multiplied in an environment where it expresses male fertility trait while hybrid seeds can be produced in other environment, where it expresses male sterility. Male (pollen) fertility in hybrid crop is not affected, as male parent contributes normal (wild) allele of the environmental sensitive mutant gene. Since only two parental lines are involved, breeding method involving EGMS is more popularly termed as "Two Line Hybrid Breeding".

\section{Utilization of marker gene}

The non-lobbing leaf character governed by a single recessive gene which is expressed in the seedling stage can be used as a marker gene for easy and economical production of hybrid seed in water melon (Whitaker and Davis, 1962). The inbred lines of non-lobed and lobed may be planted in alternate rows and seeds are collected from the non-lobed lines only. The FI hybrids having lobed leaves can be easily distinguished in the seedling stage. However, about 6-8 seeds/hill may be sown because on an average only one third of the plants will be FI hybrids.

Swarup and Gill (1964) have suggested the use of marker gene in cabbage for purple stem pigmentation to facilitate the identification of FI hybrid seedlings before transplanting. A recessive marker gene for glossy foliage is being used in brussels sprout for the production of FI hybrid seeds (North and Priestley, 1962). However, Johnson (1966) has advocated incorporation of recessive marker gene in both A and B line in brussels sprout and suggested partial chlorosis character for this purpose besides the glossy foliage.

Davis (1966) has suggested a new method for producing the hybrid seeds in onion using a brown seeded inbred line in which brown seed coat colour is linked with male sterility. The brown seed coat colour is governed by a single recessive gene. The brown seeded male sterile line and the black seeded pollen parent line can be used for producing hybrid seeds. The hybrid seeds harvested from the male sterile line will be black in colour. This method is also useful in rouging off types occurring in the male sterile seed parent and male fertile pollen parent.

\section{Limitations of GMS}

Because of more tedious maintenance process and non-availability of suitable marker gene among the vegetable crops, GMS are utilized commercially only in chilli and muskmelon in India.

\section{Transgenic genetic male sterility system (Barnase-Barstar system)}

Genetic engineering of male sterility can selectively and specifically destroy or interfere 
with the normal development of anthers or pollen. Although engineered male sterility systems are not currently in commercial use, except for possibly the barnase barstar system, these are likely to have significant importance in future hybrid-breeding programs. The genetic modification technique involves development of male sterile transgenic plants by inserting the gene sequences that are active only in the male reproductive organs and destroy or interfere with pollen or anther development (microsporogenesis). This results in purely female ("male-sterile") plants that can then be used for cultivation purposes and for the production of hybrid seeds. The development of transgenic male sterility system has been made possible because of isolation, cloning and characterization of anther or pollen specific genes and promoter sequences. These genes are expressed in pollen themselves (gametophytic expression) or cells and tissues (sporophytic expression) that directly or indirectly support pollen development, such as tapetum, filament, anther wall etc. (Kumar et al., 2000). However, the sterile source does not exist in all vegetable crops, which may be obtained by searching in nature, artificial mutation and protoplast fusion. The rapid development of plant genetic engineering offers a shortcut for creating male sterile materials.

\section{Barnase-Barstar system (Abolition- restoration system)}

In this system, to develop transgenic male sterile plants, process of pollen development is disrupted (abolished; hence the term abolition) by the exogenous trans-gene constructs. Such trans-genes usually code for cytotoxic compounds like RNAase, lipase, protease etc., which are disruptive to the cellular integrity. The expression of such genes is directed by tissue specific promoter either in developing pollen or in pollen development supporting tissues (usually tapetum cells), which causes abolition of gametophytic and sporophytic cells, consequently resulting in male sterility. For pollen fertility restoration, another transgene which inhibits the action of disruptive gene is used.

One of the classical examples of this system is first transgenic male sterility system (popularly known as Barnase- Barstar system), developed by Mariani and his associates in rapeseed and tobacco (Mariani et al., 1990; 1992). Transformed plants were developed using the chimeric RNAase gene (called Barnase) containing tapetum specific promoter (TA29). Since Barnase (cytotoxic) is expressed in the tapetum cells of transformed plants, tapetum cell and pollen development was checked which resulted in male sterile transgenic plants (Mariani et al., 1990). However, homozygosity of Barnase gene in such male sterile plant cannot be achieved and difficulty in maintenance remains a handicap. Crossing of transgenic male sterile plants (hemizygous; Barnase -) with normal plants will produces $50 \%$ hemizygous (Barnase -) male sterile F1s. Therefore, as such these male sterile plants cannot be utilised in those crops where fruits or seeds are of economic value.

These problems (seed increase of male sterile plants and restoration of fertility in F1) have been addressed (Mariani et al., 1992). It was demonstrated that fertility in F1s derived from transgenic male sterile plants (dominant) could be restored by developing F1s from the pollen of another transgenic plants possessing Barstar gene coupled with TA29 promoter. In the F1 plants, product of Barstar gene is dominant suppressor of cytotoxic products of chimeric RNAase. Transcript of Barstar gene formed complexes with chimeric RNAase transcribed from TA29-Barstar gene in tapetum cells (Mariani et al., 1992). To overcome maintenance problem transgenic with Barnase::herbicide resistant gene (linked) construct has been developed. Since male 
sterility gene (Barnase) is linked with the herbicide resistant gene, in such cases hemizygous male sterile plants can be crossed with normal sister plants and spraying of herbicide on the progenies, will ensure survival of $50 \%$ sterile segregants and elimination of $50 \%$ fertile segregants.

\section{Cytoplasmic male sterility}

This male sterility is governed by cytoplasmic factor (sterile cytoplasm) and is found in carrot, sweet pepper, radish, turnip, cauliflower, cabbage, broccoli, Chinese cabbage and cucumber. Cytoplasmic male sterility is a maternally inherited trait, because mt-genome is responsible for the expression of male sterility and the mitochondria are usually excluded from the pollen during fertilization. Since the cytoplasm of a zygote comes primarily from egg cell, the progeny of such male sterile plants would always be male sterile.

CMS can be transferred easily to a given strain by using that strain as a pollinator (recurrent parent) in the successive generations of backcross programme. After 6-7 backcrosses, the nuclear genotype of the male sterile line would be almost identical to the recurrent pollinator strain.

In cabbage, cauliflower and broccoli, cytoplasmic male sterility has not apparently been found but it has been introduced from different sources like sterile cytoplasm of radish and black mustard. Three Ogura based improved CMS lines of cauliflower were developed following seven generations of backcrossing with snowball group. This male sterility is sensitive to temperature and is unstable under fluctuating environments which hinders its utilization in hybrid seed production. CMS plants have also been developed in several vegetables through protoplast fusion (Pelletier et al., 1995).

\section{Utilization of CMS}

Cytoplasmic male sterility can be maintained by crossing a male sterile line ( $A$ line) with the pollinator strain (maintainer line) used as a recurrent parent in the back cross programme since the nuclear genotype of the pollinator is identical with that of the new male sterile line. However, cytoplasmic male sterility has been successfully exploited at IARI Regional Research Station, Katrain to develop the cabbage hybrid "H 64".

\section{Cytoplasmic - genic male sterility}

Once dominant restorer allele (located in nuclear genome) for pollen fertility of a cytoplasmic male sterile line is identified, it is commonly known as cytoplasmic- genic male sterility (CMS). Hence male sterility in CMS expressed under the presence of sterile mtgenome located in cytoplasm (S-cytoplasm) and recessive allele of restorer (maintainer allele; r) located in the nuclear genome. This male sterility is conditioned by the interaction of nuclear gene and sterile cytoplasm but neither the genetic factor nor the cytoplasmic factor alone can regulate sterility. Fertility restorer gene should be present in homozygous $\mathrm{Rf} / \mathrm{Rf}$ state i.e. either $\mathrm{S} \mathrm{Rf} / \mathrm{Rf}$ or $\mathrm{N} \mathrm{Rf} / \mathrm{Rf}$ where seed production is important.

Along with the sterile cytoplasm, the sterility is determined by a single recessive gene (ms ms) in onion, radish, cabbage, cauliflower, chilli and sweet pepper; by two recessive genes ( $\mathrm{xx} \mathrm{zz}$ ) in beet and by a dominant gene (Ms ms or Ms Ms) in carrot. However, the sterility in carrot and beet is found to be unstable due to the presence of modifying genes. Cyto-nuclear male sterility has been extensively exploited for hybrid seed production in onion and carrot. However, this system is sensitive to environmental factors and change in environment leads to restoration of fertility and contamination of hybrid seeds. 


\section{Limitations of CGMS}

Non availability of CGMS in many crops and their wild relatives.

Need of fertility restorer allele in fruit producing vegetables.

Undesirable pleiotropic effect of sterile cytoplasm on horticultural qualities.

Breakdown of male sterility in particular environments.

\section{Chemical Hybridizing Agents (CHA)}

Chemical hybridizing agent (CHA) are the chemicals that induce male sterility in plants. Potential of certain chemicals (maleic hydrazide) to induce selective male sterility was first demonstrated during 1950 in maize (Moore, 1950; Naylor, 1950).

It was recognized that despite of certain disadvantages there might be some advantages, especially in terms of time required to identify economically viable hybrids. This is because chemical methods for inducing male sterility can obviate the lengthy time frame required to obtain male sterile and restorer lines.

\section{Site and mode of action of CHA}

The most important general feature revealed from the literatures is that the earlier developed compounds (e.g. FW-450, ethephon, RH-531, PPX 3778) can induce a range of specific effects that are dependent upon treatment time and dosage interaction.

Some general effects includes the followings (McRae 1985):

Meiosis is disrupted at early stage and anther development stage is arrested at an early stage.
Exine formation is disrupted and microspores are thin walled, distorted in shape and nonviable.

Microspores vacuole abnormalities, decreased starch deposition and persistent tapetum. Pollen is non-viable but anthers are normal.

Pollen is present and viable but anthers either do not dehisce or show delayed dehiscence.

\section{Mechanisms of male sterility}

\section{Cytological changes}

Breakdown in the process of microsporogenesis can occur at a pre-or postmeiotic stage. The abnormalities can involve aberration during the process of meiosis in the formation of tetrads, during the release of tetrad (the dissolution of callose), at the vacuolate microspore stage or at mature or near-mature pollen stage

\section{Biochemical changes}

Male sterility is accompanied by certain biochemical changes such as qualitative and quantitative changes in amino acids, protein, and enzymes in developing anther.

It has been found to be associated with reduced levels of proline, leucine, isoleucine, phenylalanine and valine and increased levels of glycine, arginine and aspartic acids (Kaul, 1988).

Level of proline has been found to be particularly affected. Kakihara et al., (1988) reported that mature male sterile anthers contain one-eighth amount of proline in comparison to the fertile anthers. Anthers of male sterile plants contain lower soluble protein content and fewer polypeptide bands. Some polypeptides synthesized in normal stamens were absent in mutant stamens. 


\section{Classification of male sterility in plants (Kaul, 1988)}

(i) Inherited (genetic) male sterility

\begin{tabular}{|c|c|}
\hline \multirow[t]{3}{*}{ Phenotypic basis } & $\begin{array}{l}\text { (i) Sporogenous male sterility. Pollen formation is completely } \\
\text { disrupted. Stamens are formed but there is absence of pollen due to } \\
\text { abortion of microsporogenous cell which occurs before, during or after } \\
\text { meiosis. }\end{array}$ \\
\hline & $\begin{array}{l}\text { (ii) Structural sterility or positional sterility. Floral organs are } \\
\text { modified in such a way that selfing does not occur. Stamens are either } \\
\text { absent, malformed or modified into other floral parts which leads to } \\
\text { absence of microsporogenesis. e.g. tomato, lima bean and onion. }\end{array}$ \\
\hline & $\begin{array}{l}\text { (iii) Functional sterility. Viable pollens are produced but they are unable } \\
\text { to self fertilize due to some barriers (non-dehisent nature of anthers). } \\
\text { Seed setting occurs when artificially selfed by its own pollen or crossed } \\
\text { with other pollen. }\end{array}$ \\
\hline \multirow[t]{3}{*}{ Genetic basis } & 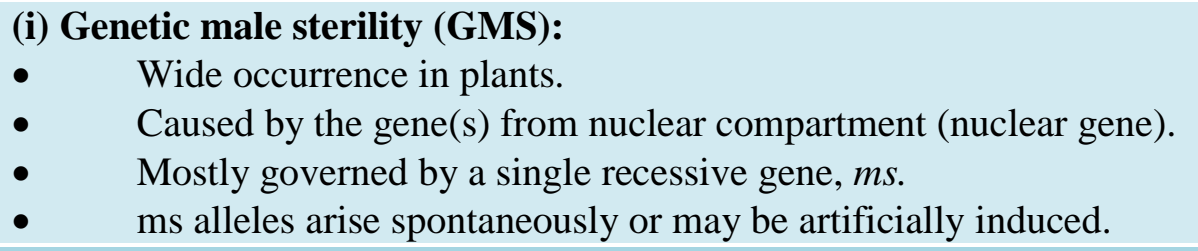 \\
\hline & $\begin{array}{l}\text { (ii) Cytoplasmic male sterility (CMS). } \\
\text { Determined by cytoplasm. } \\
\text { - } \quad \text { Result of mutation in the mitochondrial genome (mtDNA). } \\
\text { Can be easily transferred to a given strain. }\end{array}$ \\
\hline & $\begin{array}{l}\text { (iii) Cytoplasmic-genic male sterility (CGMS). } \\
\text { Male sterility is caused by mitochonridal genes and restored by } \\
\text { the nuclear genes. } \\
\text { - } \quad \text { Also known as nucleoplasmic male sterility. } \\
\text { - } \quad \text { Fertility restorer gene } R \text { is required. }\end{array}$ \\
\hline $\begin{array}{l}\text { (ii) Non-inherited (non- } \\
\text { genetic) male sterility }\end{array}$ & $\begin{array}{l}\text { This kind of male sterility is temporarily induced by certain } \\
\text { environmental stresses e.g., temperature, etc. } \\
\text { (i)Chemical, (ii) Physiological and (iii) Ecological }\end{array}$ \\
\hline
\end{tabular}

\begin{tabular}{l|l|l|}
\hline \multicolumn{3}{l}{ Environmental sensitive male sterile mutants } \\
\hline Vegetable & Mutant & Reference \\
\hline Cabbage & TGMS, PGMS & Rundfeldt, 1961 \\
\hline Brussels sprouts & TGMS & Nieuwhof, 1968b \\
\hline Broccoli & TGMS & Dickson, 1970 \\
\hline Pepper & TGMS, TCMS & Daskalov, 1972; Shifriss, 1997* \\
\hline Carrot & TGMS & Kaul, 1988 \\
\hline Tomato & TGMS & Rick, 1948; Sawhey, 1983 \\
\hline TGMS - Thermo sensitive genic male sterility \\
\hline PGMS - Photoperiod sensitive genic male sterility \\
\hline *TCMS - Thermo sensitive cytoplasmic male sterility
\end{tabular}




\begin{tabular}{|c|c|c|}
\hline \multicolumn{3}{|c|}{ Linkage of ms gene with the marker gene in vegetables } \\
\hline Vegetable & Marker gene for & Reference \\
\hline Broccoli & Bright green hypocotyle & Sampson, 1966 \\
\hline \multirow[t]{3}{*}{ Tomato } & $\begin{array}{l}\text { Potato leaf shape and green } \\
\text { stem colour }\end{array}$ & Kaul, 1988, \\
\hline & Parthenocarpic fruit & Soressi and Salamini, 1975 \\
\hline & Enzyme marker & Tanksley et al., 1984 \\
\hline Watermelon & Delayed green seedling & Zhang et al., 1996 \\
\hline Cabbage & $\begin{array}{l}\text { Purple Stem Pigmentation in } \\
\text { seedling }\end{array}$ & Swarup and Gill, 1964 \\
\hline Muskmelon & Glabrous seedling & Foster, 1963 \\
\hline Onion & Brown seed coat colour & Davis, 1966 \\
\hline \multirow[t]{2}{*}{ Brussels Sprout } & Glossy Foliage & North and Priestley, 1962 \\
\hline & Partial Chlorosis character & Johnson, 1966 \\
\hline
\end{tabular}

Male sterility in vegetables

\begin{tabular}{|l|l|l|l|}
\hline Mutant & Description & Inheritance & Governing genes \\
\hline Pollen sterile & Pollen abortive & $\begin{array}{l}\text { Monogenic recessive } \\
\text { (except MS-48, } \\
\text { monogenic dominant) }\end{array}$ & ms series \\
\hline Stamenless & Stamens absent & Monogenic recessive & $s l-1, s l-2$ \\
\hline Positional sterility & Stigma exerted & Monogenic recessive & $p s$ \\
\hline Functional sterility & Anthers do not dehisce & Monogenic recessive & $p s-2$ \\
\hline
\end{tabular}

Musk melon

\begin{tabular}{|c|}
\hline Male sterile alleles \\
\hline$m s-1$ \\
\hline$m s-2$ \\
\hline$m s-3$ \\
\hline$m s-4$ \\
\hline$m s-5$ \\
\hline
\end{tabular}

\begin{tabular}{l}
\multicolumn{1}{|c|}{ Reported by } \\
\hline Bohn and Whitaker (1949) \\
\hline Bohn and Principe (1962) \\
McCreight and Elmstrom (1984) \\
Pilrat (1990) \\
\hline Lecouviour et al., (1990)
\end{tabular}

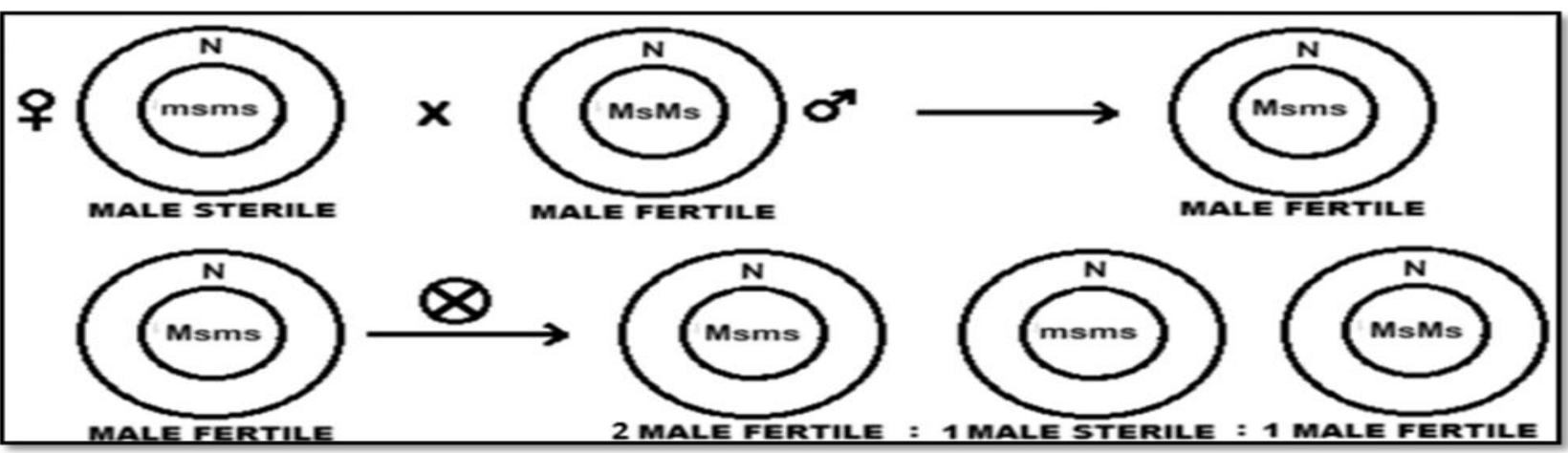

Inheritance pattern of genetic male sterility 


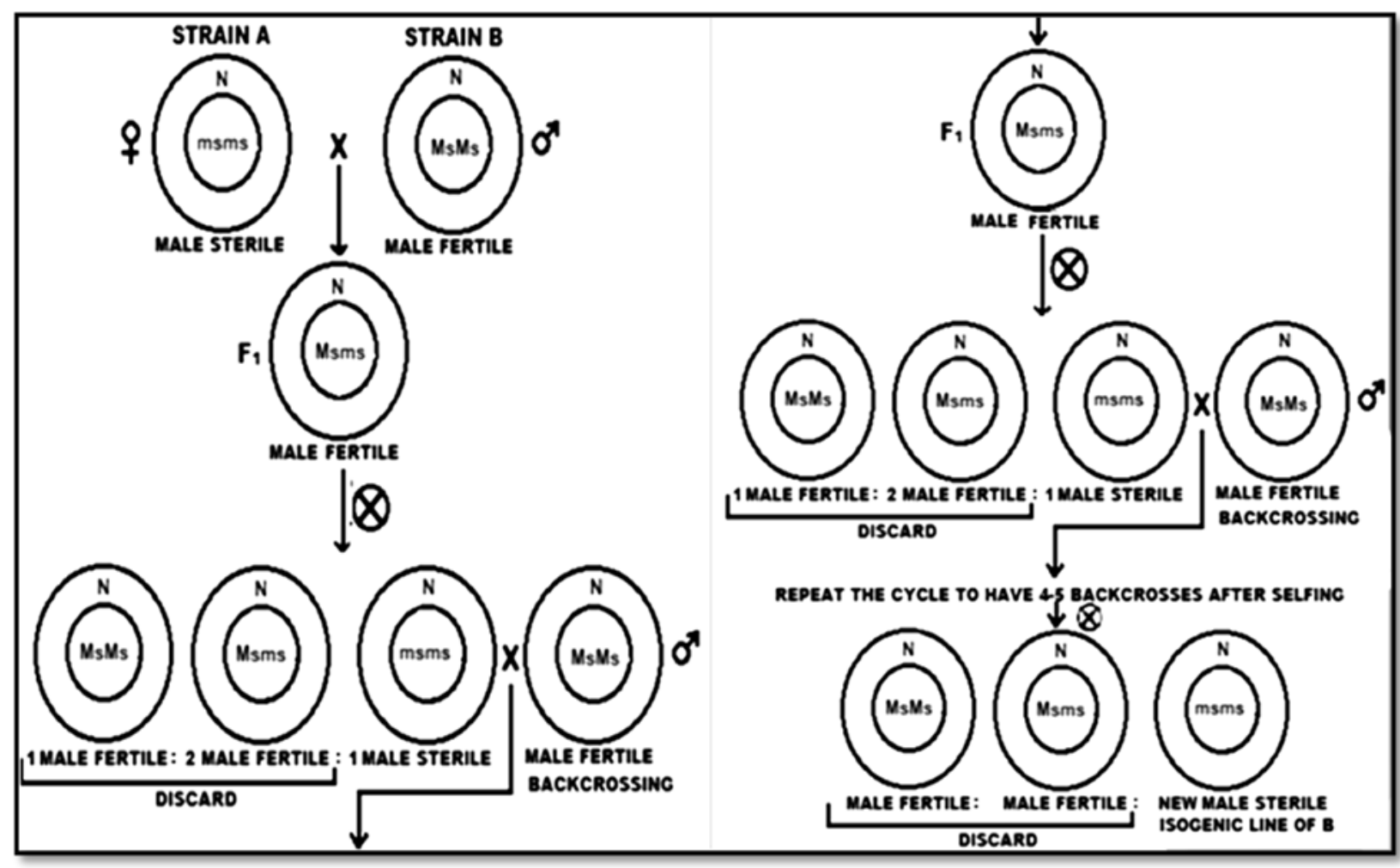

Transfer of genetic male sterility to a new strain

Male sterile seeds multiplication field

Hybrid seed production field

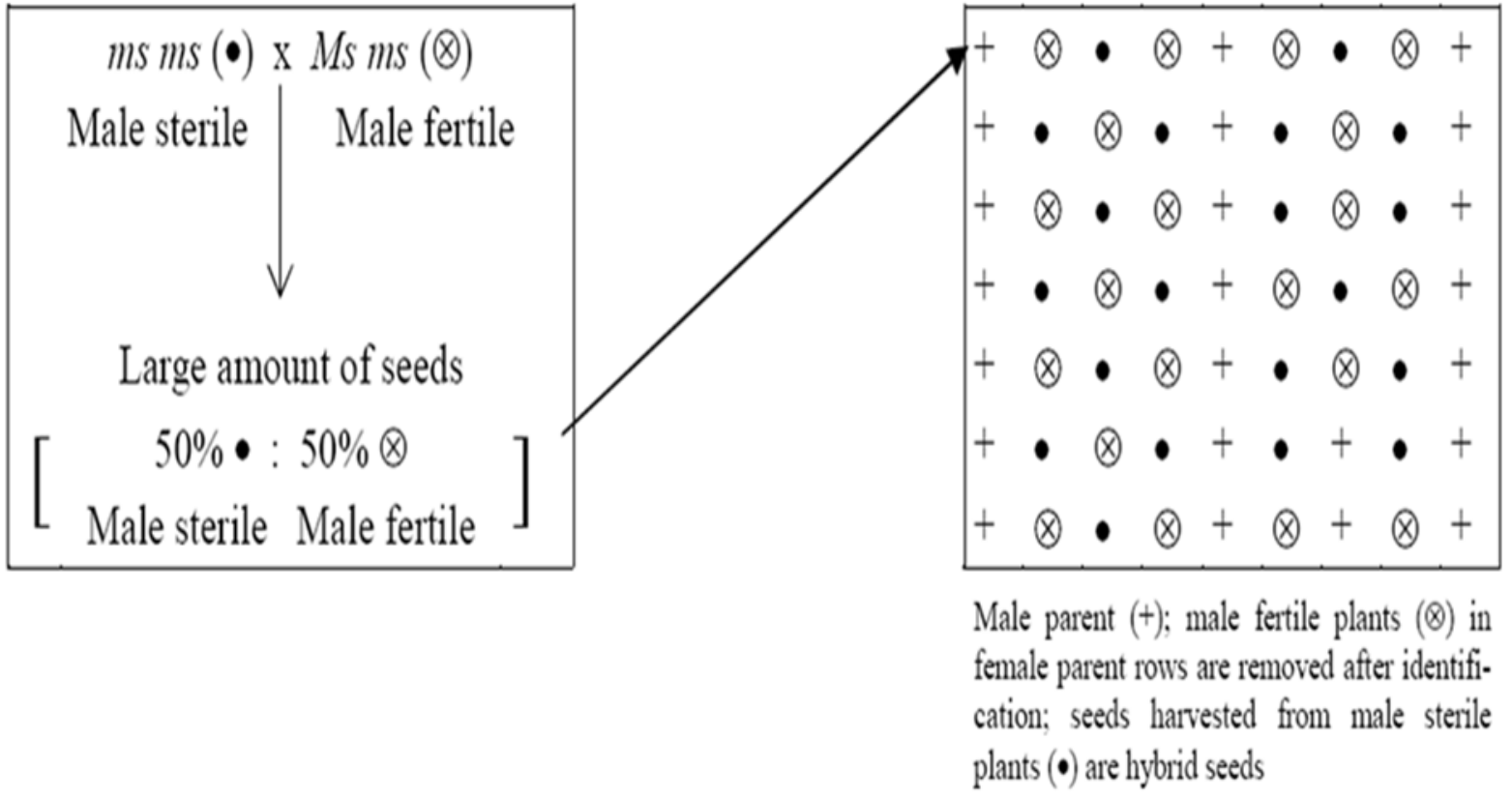

General scheme of hybrid seed production utilizing GMS 


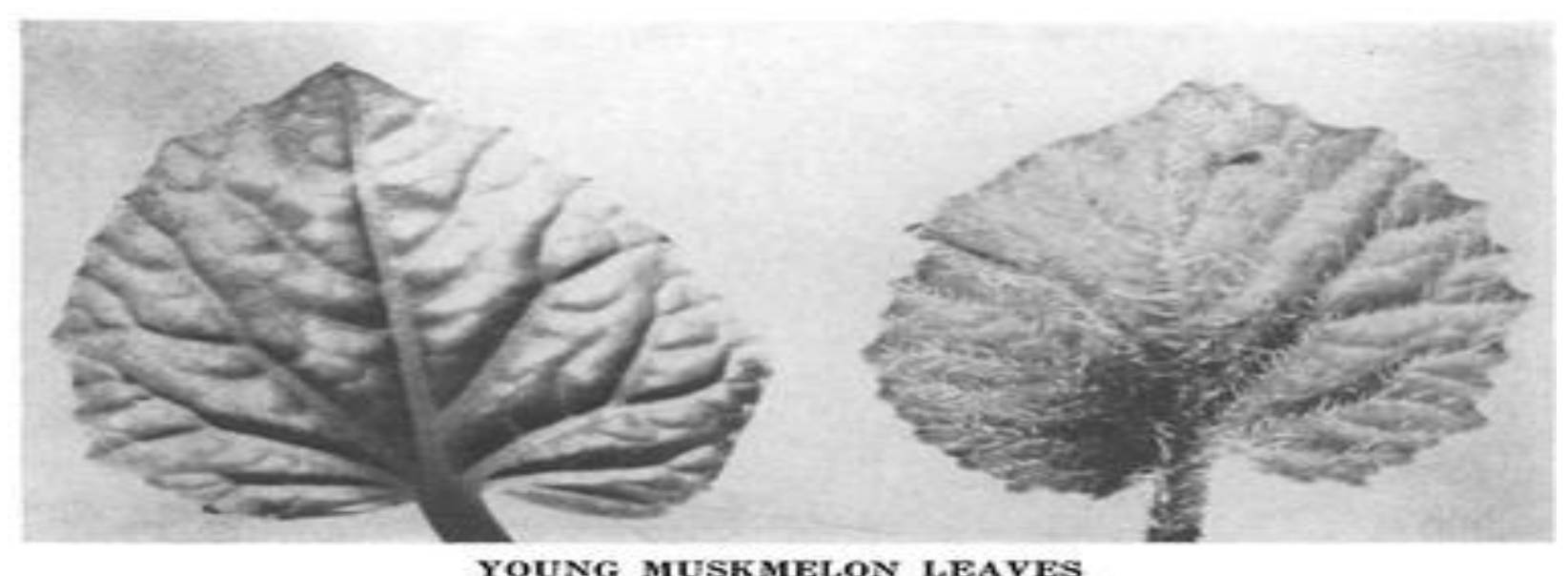

Glabrous, A New Seedling Marker in Muskmelon (Foster, 1963)

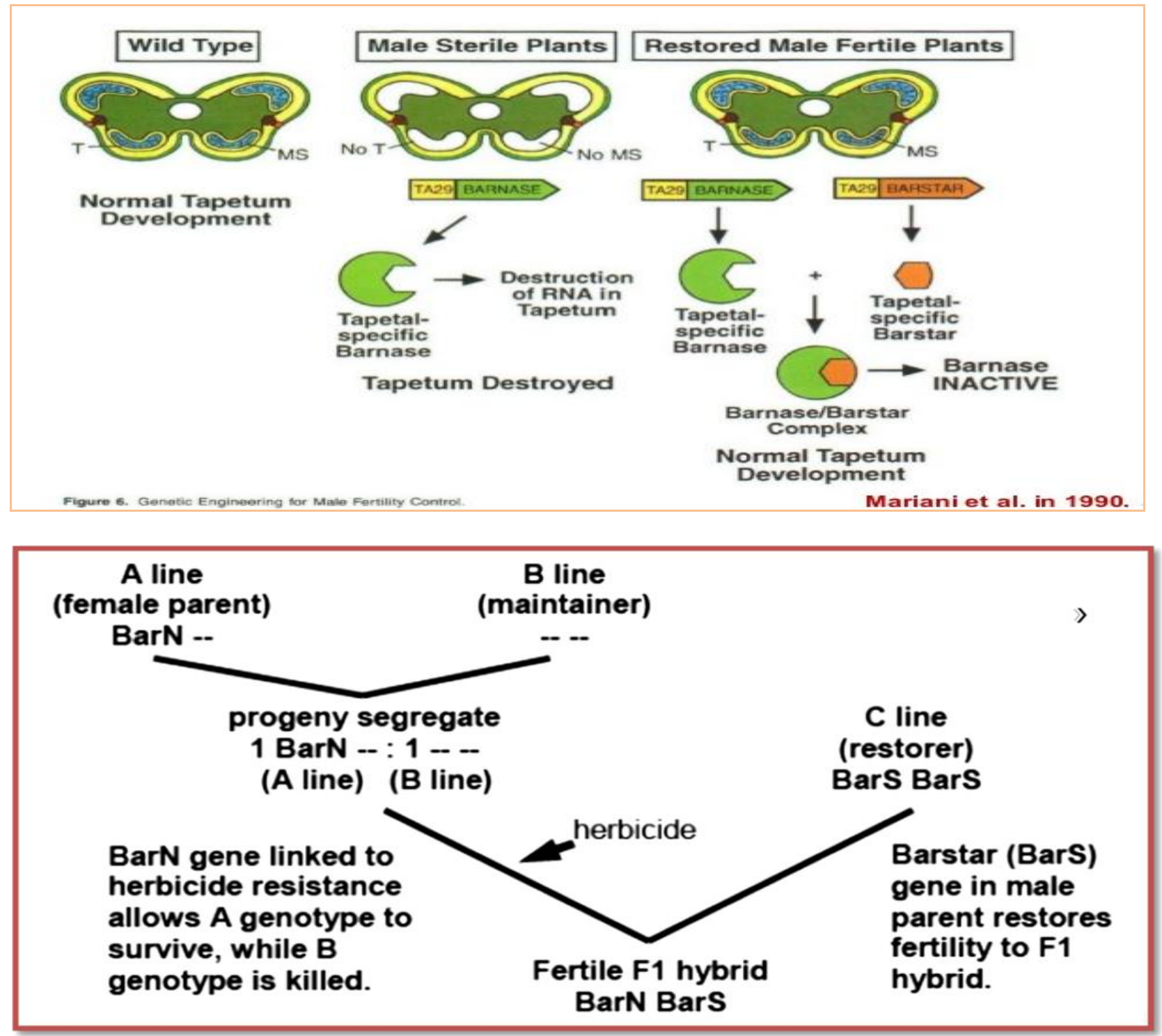



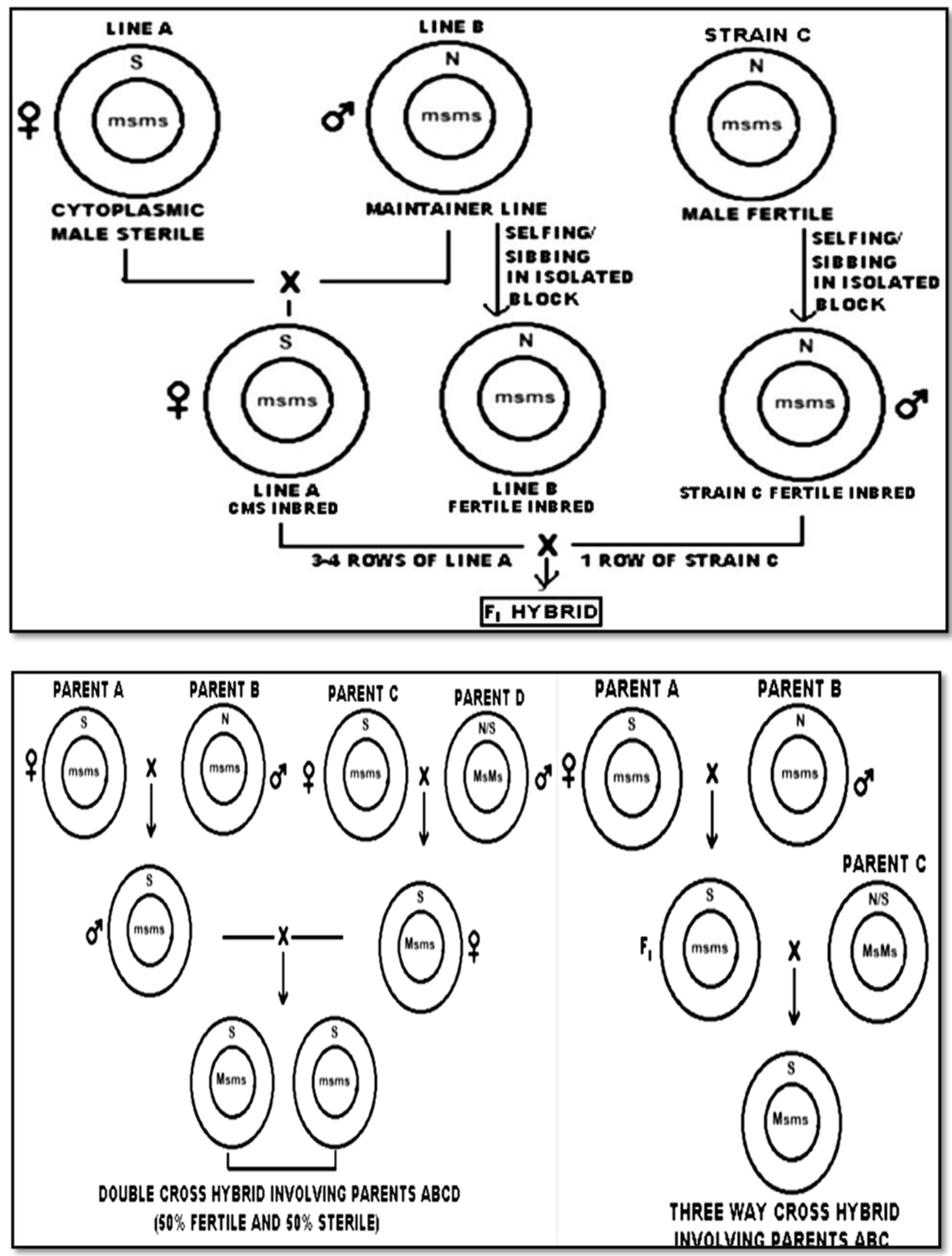

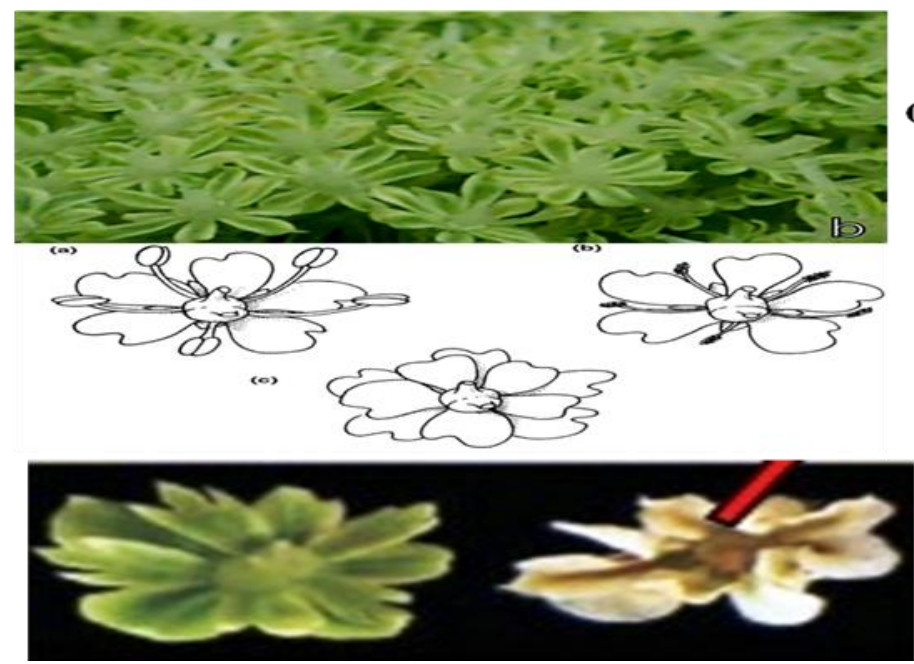

(a) Petaloid CMIS $(S p)$

(b) Brown anther CMIS (Sa)

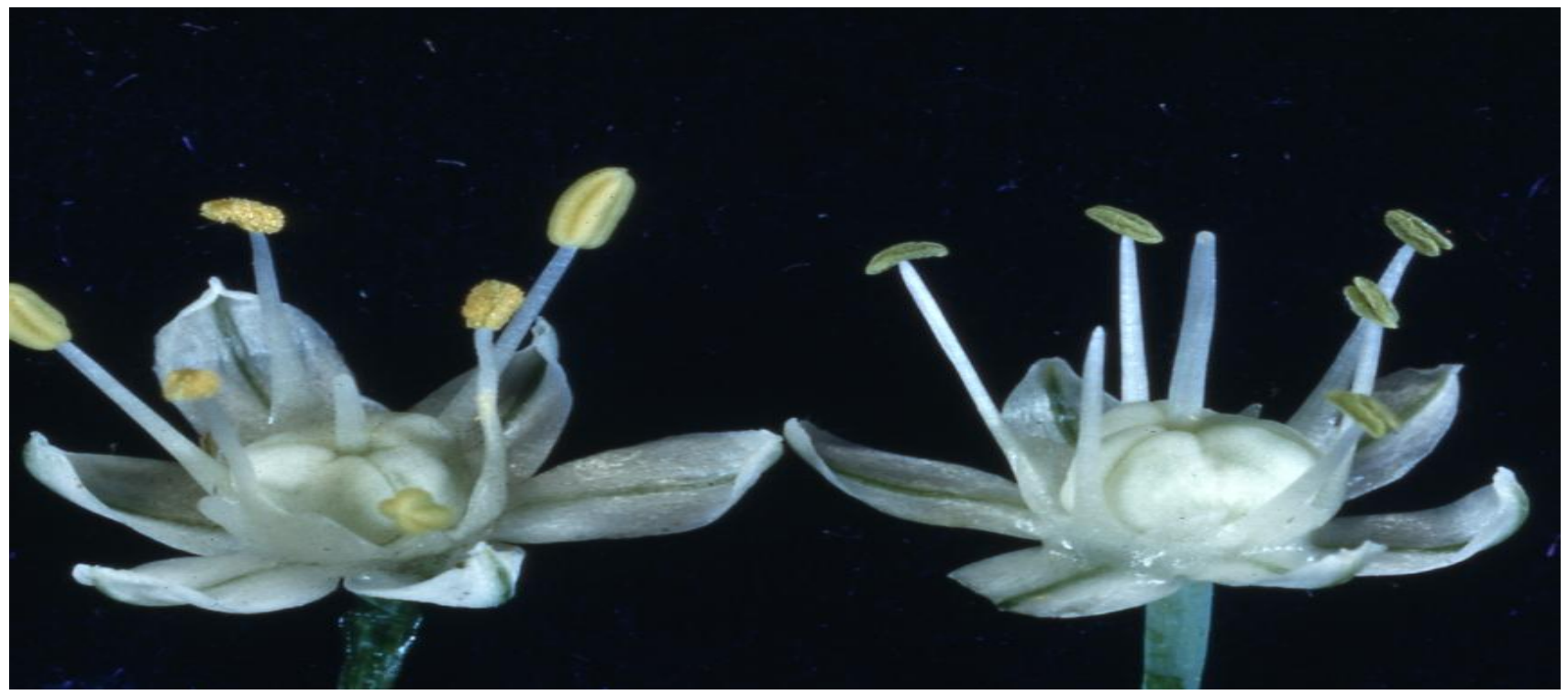

Male Fertile

Male Sterile

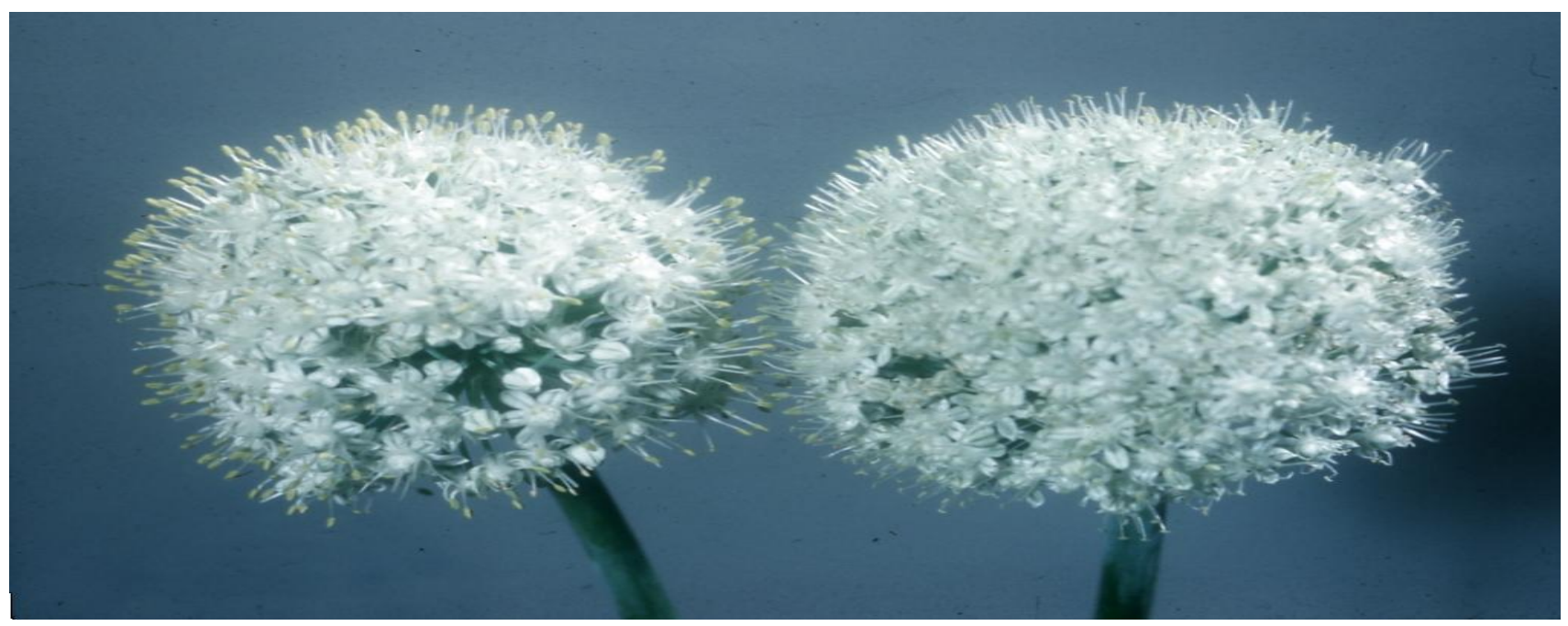

Male Fertile

Male Sterile 
The activity of enzyme callase which is required for breakdown of callose that surrounds PMCs and the tetrad is decreased in male sterile anthers. Low activity callase leads to premature or delayed release of meiocytes and microspore, resulting in male sterility. Male sterility is also accompanied by decreased activity of isozyme esterase which plays an important role in hydrolysis of sporopollenin polymer that is required for pollen formation. Decreased activity of esterase in male sterile plants has been observed in tomato (Bhadula and Sawhney, 1987) and radish (Zhou and Zhang, 1994). Compared to fertile lines, there is reduced activity of amylase in male sterile anthers and it corresponds with high starch content and reduced levels of soluble sugars.

\section{Male sterility in vegetables}

\section{Solanaceous vegetables}

\section{Tomato}

There are five types of male sterility in tomato but only pollen abortive type (sporogenic) and functional sterility have been exploited for hybrid seed production. Other male sterility mechanisms are associated with defective fruit development in the hybrid progeny.

\section{GMS}

More than 55 male sterile $(m s)$ alleles causing sporogenous, structural and functional sterility have been reported (Kaul, 1988). Chromosomal locations of some genes is also known. Two stamenless mutants, viz., stamenless-1 (sl-1) and stamenless-2 (sl-2) produce flowers without stamens when grown at higher temperature, while those grown at low temperature produce flowers with abnormal stamens and often with viable pollen. Similarly in $m s-15$ and $m s-33$ mutans, low temperature $\left(30^{\circ} \mathrm{C}\right)$ is reported to be associated with fertility restoration (Sawhney, 1983).

\section{CMS}

Through protoplast fusion of Lycopersicon esculentum with Solanum acaule and S.tuberosum, CMS hybrid plants have been isolated with different flower morphology than tomato. Recently, sterile cytoplasm from $L$. peruvianum has been transferred into the $L$. pennellii. Subsequently, CMS pennellii has been successfully crossed with esculentum. This hybrid provides basis for the development of CMS system in tomato derived from sterile cytoplasm of peruvianum. However, the practical utility of CMS would depend upon the identification of restorer gene in tomato.

\section{Chilli (Capsicum annuum L.)}

\section{GMS}

The genetic male sterility is an important pollination control mechanism which is exploited commercially for hybrid seed production in chilli. The induced male sterile allele in France $(m c-509)$ was later renamed $m s-10$. The $m s-10$ line was introduced in India at Punjab Agriculture University and recessive male sterile allele (msms) was introgressed into three chilli genotypes viz., MS12, MS13 and MS41. The male sterile line (MS-12) was developed by transferring sterility gene $m s-10$ from capsicum (imported from France) into the cultivar 'Punjab Lal' through back crossing (Singh and Kaur 1986). By using this male sterile line (MS-12), PAU has released three chilli hybrids viz. $\mathrm{CH}-1$ $(\mathrm{MS}-12 \times$ LLS), CH-3 (MS- $12 \times 2025)$ (Dhall, 2011) and CH-27 (MS-12 x S-343). A GMS line, "ACMS2", having mongenic recessive gene (acms2acms2) is reported (Patel, et al., 1998). The ms-3 line introduced 
from Hungary is maintained at AVRDC, Taiwan (Berke, 1999).

\section{CGMS}

The CGMS in chilli was first reported by Peterson, 1958 in an introduction of $C$. annuum from India (PI-164835), however, it has not been exploited commercially, because of instability under fluctuating conditions, particularly temperatures and a low rate of natural cross pollination in cultivated hot pepper (Kumar et al., 2007). The World Vegetable Centre, Taiwan has identified two CGMS lines (A lines) in chilli i.e. CCA-4759 and CCA-4757, which were found to be reliably sterile under conditions of night temperatures less than 15 degree Centigrade (Liu and Gniffke 2004). CGMS lines (CCA4261) of chilli introduced at the IIVR from AVRDC are utilized to produce hybrid- Kashi Surkh (CCH-2). Three CGMS based hybrids i.e. Arka Meghna (MSH-172), Arka Harita (MSH-149) and Arka Sweta (MSH-96) have been developed at IIHR, Bangalore.

\section{Musk melon}

Five male sterile genes ( $m s-1, m s-2, m s-3, m s$ 4 , and $m s-5$ ) have been identified in melon and all of them are recessive and nonallelic.

In India, male-sterile gene $m s-1$ was introduced in 1978 and used to release two commercial cultivars 'Punjab Hybrid' (Nandpuri et al., 1982) and 'Punjab Anmol' (Lal, et al., 2007). Due to the instability of this $m s-1$ gene in sub-tropical field conditions, the seed production of these hybrids has posed numerous problems consistently (Dhatt and Gill, 2000).

\section{Watermelon}

The first male sterility in Watermelon, Citrullus lanatus (Thunb.) was reported by
Watts (1967) who found a male sterile mutant in the X2 generation of 'Sugar Baby' irradiated with gamma rays. The mutant was described as a glabrous male sterile $(\mathrm{gms})$ due to the associated lack of hairs on the plant foliage. Glabrousness and male sterility were inherited together as a single recessive nuclear gene, suggesting very close linkage or a pleiotropic effect of the locus involved (Watts, 1967). The gms gene not only disrupts the male reproductive function, but also reduces female reproduction (Watts, 1967). Therefore, there has been little commercial application of the gms gene.

\section{Okra [Abelmoschus esculetus (L.) Moench.]}

In India, commercial production of $\mathrm{F} 1$ hybrid in okra is done by hand emasculation and hand pollination which is a tedious process that takes $70 \%$ of the time and labour in cultivation. Geneic Male Sterile (GMS) line MS-1 identified by the Division of Vegetable Crops, IIHR is being used for development of a commercial F1 hybrid. Male sterility in okra is controlled by a pair of single, recessive genes when present in the homozygous (ms Ims l) condition and can be utilized by hybrid seed production. In okra, male sterility has not been observed in nature, but, has been induced by gamma radiation (Dutta, 1971). The gene was stable, not being influenced by environmental factors. Anthesis was normal but anther dehiscence was partial. Microsporogeneisis was normal upto the tetrad stage. Hence, a great future for hybrid seed production is envisaged in a heterosis breeding programme (Pitchaimuthu et al., 2012).

\section{Cole crops (Brassica oleraceae $\mathbf{L}$.)}

In cole crops, F1 hybrids are advantages especially in uniform maturity, high early and total yield, better curd/ head quality with respect to compactness, colour, resistance to 
insect- pests, diseases and heat tolerance. There are two pollination control mechanisms are working in cole crops such as selfincompatibility and male sterility, which are used in the commercial hybrid seed production of crops. However, SI system has several disadvantages like, possibility of sibs in the hybrids and multiplication of SI parents through tedious bud pollination. SI is commercially employed for hybrid development in Indian cauliflower. The climate change is anticipated to pose a threat to such hybrids, as SI, being thermosensitve, breaks and increases percentage of self's in hybrid seed lots (Kalia, 2008). In such situation, male sterility system offers a better alternative for hybrid development in these crops. Genic male sterility has been reported in most of the cole crops (Nieuwhof, 1961; Dickson, 1970). In brusselsprout (Johnson, 1958), cabbage (Nieuwhof, 1961) recessive genes $(\mathrm{ms})$ controlling male sterility has been reported. However, in broccoli (Duneman and Grunewaldt, 1987), and cauliflower (Crisp and Tapsel, 1993) dominant gene(s) controlling male sterility has been also reported. A dominant male sterile gene $M s c d l$ was identified as a spontaneous mutation in a spring cabbage line 79-399-3. This male sterility is well utilized to produce commercial hybrid cabbage seed production in china.

In Brassica oleraceae L. first CMS system was developed by Pearson, 1972 through inter- specific hybridization between $B$. nigra and $B$. oleraceae var italica. Back crosses were also made between the amphidiploids and cabbage cultivar Green Globe and from these materials Pearson established two CMS systems, viz., petaloid and vestigial anther male sterility. Flowers of petaloid male sterile plants were less attractive to the pollinating insects, since pistils were enlarged, malformed and were lacking in nectarines (Pearson, 1972). In vestigial anther types, although flowers were smaller, normal and with functional nectarines, homozygous plants could not be recovered even after six generations of backcrossing in broccoli (Dickson, 1975).

\section{Ogura cytoplasm}

CMS has been reported in an identified cultivar of Japanese radish by Ogura (1968) and first alloplasm was introduced by introgression of this sterility cytoplasm to Brassica oleraceae genome through repeated backcrosses with broccoli (Bannerot et al., 1974). The curd yield is increased $40-75 \%$ compared to SI system from different maturity groups (Kalia, 2008). Recently Ogura based CMS lines developed in snowball cauliflower viz., Ogu1A, Ogu2A and Ogu3A for hybrid development in cauliflower. In India, IARI regional station Katrain develops two Cabbage hybrids H-64 \& $\mathrm{KCH}-4$ using cytoplasmic male sterility.

\section{Anand cytoplasm}

The 'Anand' cytoplasm derives from the wild species B. tournefortii. It was transferred from $B$. rapa to $B$. oleraceae through cybridization process. The presence of 'Anand' chloroplasts with a $B$. oleracea nucleus did not result in cold temperature chlorosis, as seen in 'Ogura' CMS plants (Cardi and Earle, 1997). One such CMS system 'tour' which is derived from Brassica tournefortii, induces additional floral abnormalities and causes chlorosis in Brassica spp (Arumugam et al., 1996).

\section{Root crops}

\section{Carrot (Daucus carota L.)}

\section{CGMS}

There are three types of male sterility in carrot: 
Brown anther (ba) (Welch and Grimbal, 1947)

Petalloid (pt) (Thompson, 1962)

Gummifer (Nothnagel, 1992)

\section{Brown anther type}

The brown anther $(b a)$ male sterility was first discovered in the cultivar Tendersweet and reported by Welch and Grimbal in 1947. Brown anther type male sterility is due to the interaction of "sa cytoplasm" with atleast two independent recessive nuclear genes. Expression of the brown anther sterility was due to a homozygous recessive locus $M s 5$ or a dominant allele for $M s 4$, but dominant allele of either of the two complimentary loci would restore the fertility.

\section{Petaloid male sterility}

Petaloid sterility is commercially used for hybrid seed production in the world. According to Morelock (1974), the $p t$ type of male sterility is due to interaction between "Sp cytoplasm" and two independent dominant genes (M1 and M2). This is manifested as the replacement of stamens with petals (white petaloidy) or both stamens and petals with green bract like structures (green petaloidy) (Kitagawa, et al., 1994). It is stable across a wide range of environments through flowering and seed production.

CMS system has been established for the first time in Asiatic carrot germplasm in India at IARI.

In India, at IARI, petaloid CGMS was transferred to nantes type and crossed it with the indigenous variety "Pusa yamdagini" to develop hybrid Pusa nayanjyoti in 2009. Cytoplasmic male sterility system has been established for the first time in tropical carrot and tropical carrot hybrid "Pusa Vasudha" has been developed which is the first from any public sector institution.

\section{Onion}

\section{CMS}

First ms plant (13-53) was reported in the progenies of cultivar Italian Red (Jones and Emsweller, 1936). It is due to 2 recessive genes $m s l$ and $m s 2$. Two types of sterile cytoplasm, viz., $\mathrm{S}$ and $\mathrm{T}$ are reported, among which S-cytoplasm is exploited most widely (Pelletier et al., 1995). Arka Kirtiman (IIHR, Bangalore), Arka Lalima (IIHR, Bangalore), Hybrid-63 (IARI, New Delhi) and Hybrid-35 (IARI, New Delhi) are hybrids developed in onion through use of male sterility.

The male sterile lines of onion introduced from U.S.A., Japan and Netherlands; showed instability in India due to prevalent photoperiodism and high temperature (Korla, 1999a; Hazra and Som, 1999). The fast loss of viability of onion seeds is also a constrain for the breeders in producing the hybrid seeds (Pathak and Gowda, 1994; Kohli, 1999). Moreover, the occurrence of male sterility in Indian cultivars of onion is not frequent. Nevertheless, some naturally occurring male sterile lines are Pusa Red, Nasik White Globe and other indigenous cultivars of onion have been isolated in India (Pathak and Gowda, 1994; Hazra and Som, 1999).

Inspite of the detailed studies and understanding about the male sterility systems, still the phenomenon is not being widely used for hybrid seed production in many vegetable crops. The main reason for such under exploitation of this mechanism is non availability of stable male sterile lines, whereas in case of genetic male sterility seed multiplication of male sterile lines remains a problem. The use of biotechnology, molecular 
markers and transgenic can provide an aid for overcoming such obstacles. After examining the cost benefit ratio, it has been found that efficiency of GMS system can be further increased by the utilisation of molecular markers like RAPD (Kalloo et al., 1998). Development of practically feasible molecular markers may provide appropriate cost effective selection strategy to discard $50 \%$ male fertile sister plants at seedling stage, which may open the way to exploit monogenic recessive male sterile lines in several vegetables (Kumar and Singh, 2004). Identification of functional male sterile and EGMS lines also have great potential for being utilized in commercial hybrid seed production due to presence of functional pollen grains unlike genetic male sterility in which pollen grains are non-functional.

\section{References}

Arumugam, N., Mukhopadhyay, A., Gupta, V., Pental, D. Pradhan, A. K. 1996. Synthesis of hexaploid (AABBCC) somatic hybrids: a bridging material for transfer of 'tour' cytoplasmic male sterility to different Brassica species. Theoret. Appl. Genetics. 92: 762-768.

Bannerot, H., Boulidard, L., Cauderon, Y. and Temp, J. 1974. Transfer of cytoplasmic male sterility from Raphanus sativus to Brassica oleracea. In: Proc. Eucarpia Meet. Cruciferae, Scott. Hort. Res. Inst., Dundee, pp. 52-54.

Berke, T. 1999. Personal communication.

Bohn, G.W. and Principe, G.A. 1962. A second male-sterility gene in the muskmelon. Journal of Heredity 55: 211-215.

Bohn, G.W. and Whitaker, T.W. 1949. A gene for male sterility in the muskmelon (Cucumis melo L.). Proceeding of American Society of Horticultural Sciences 53: 309-314.

Bullard, E.T. and Stevenson, E.C. 1953. Proc. Am. Soc: Hort. Sci. 61: 451-458.

Cardi, T. and Earle, E.D. 1997. Production of new CMS Brassica oleracea by transfer of 'Anand' cytoplasm from $B$. rapa through protoplast fusion. Theor. Appl. Genet. 94: 204-212.

Chaudhari, H.K. 1992. Elementary Principles of piant Breeding. Oxford \& IBH Publ. Co. Pvt. Ltd., New Delhi. Pp.119-135.

Crips, C. and Tapsel, C. R. 1993. Cauliflower. In: Kalloo and Bergh BO (eds), Genetic Improvement of Vegetable Crops. Pergamon Press, U.K., pp. 157-177.

Daskalov, S. 1972. Male sterile pepper ( $C$. annuum L.) mutants and their utilisation in heterosis breeding. Proc. Eucarpia Meet. Capsicum 7: 202-210.

Davis, E. 1966. An improved method of producing hybrid onion seed. J. Hered.57:5557.

Dhall, R.K. 2011. Advances in Research on Male Sterility. In: K.V. Peter (eds.), The Science of Horticulture, New India Publishing Agency, New Delhi (India), pp. 113-143.

Dhatt, A.S. and Gill, S.S. 2000. Effect of genic male sterility on flowering behaviour of muskmelon. Veg. Sci., 27: 31-34.

Dickson, M.H. 1970. A temperature sensitive male sterile gene in broccoli. Brassica oleracea L. var. italica. J. Amer. Soc. Hort. Sci. 95: 13-14.

Dickson, M.H.1975. G1117A, G1102A and G1106A Cytosterile broccoli inbreds. HortScience 10: 535.

Duneman, F. and Grunewaldt, J. 1987. Male sterile broccoli (Brassica oleracea var. italica) induced by in vitro mutagenesis. Eucarpia Cruciferae Newsl. 12: 50.

Dutta, O.P. 1971. Effect of gamma irradiation on germination plant growth, floral biology and fruit production in Abelmoschus esculentus. Third International Symp. Trop. Hort., IIHR, Bangalore, India, pp. 141- 156

Foster, R. E. 1963. Glabrous, a new seedling marker in muskmelon. J Hered 54(3): 113-115.

Georgiev H. 1991. Heterosis in tomato breeding. In: Kalloo $G$ (ed), Genetic Improvement of Tomato. Monographs on Theor. Appl. Genet. 14, Springer-Verlag, Berlin, pp. 83-98.

Hazra, P. and Som, M.G.1999. Technology for Vegetable Production and Improvement. Naya Prokash, Calcutta. pp 319-362.

Johnson, A.G. 1958. Male sterility in Brassica. Nature 182:1523.

Johnson, A.G. 1966. Inbreeding and production of commercial F1 hybrid seed in Brussels sprout. Euphytica. 15: 58-79.

Jones, H. A. and Clarke, A. E. 1943. Inheritance 
of male sterility in onion and the production of hybrid seed. Proc. Amer. Soc. Hort. Sci. 43: 189-194.

Jones, H. A. and Emsweller, S. L. 1936. A male sterile onion. Proc. Amer. Soc. Hort. Sci. 34: 582-585.

Kakihara, F., Masahiro, K. and Tokumasu, S. 1988. Relationship between pollen degeneration and amino acids, especially proline, in male sterile Japanese radish (Raphanus sativus L. var. longipinnatus Bailey). Scintia Horticultare 36: 17-23.

Kalia, P. 2008. Exploring Cytoplasmic Male Sterility for F1 Hybrid Development in Indian Cauliflower. Cruciferae Newsletter. 27: 75-76.

Kalloo, G., Banerjee, M.K., Kumar, S. and Parkash, C.1998. Hybrid vegetable technology in India- an overview. In: Souvenir, Natl. Sym. Emer. Scenario in Veg. Res. Dev., PDVR, Varanasi, pp. 42-52.

Kaul, M. L. H. 1988. Male Sterility in Higher Plants. Monographs on Theor. Appl. Genet. 10, Springer-Verlag, Berlin.

Kitagawa, J. \& Posluszny, U., Gerrath, J. and Wolyn, J. D. 1994. Developmental and morphological analyses of homeotic cytoplasmic male sterile and fertile carrot flowers. Sexual Plant Reproduction. 7. 41-50.

Kohli, U.K. 1999. Development of Hybrids and their seed production in vegetable Crops. Y.S.P. Unv, Hort, Science. Forestry, Nauni, Solan. pp. 1-10.

Korla, B.N. (1999a). In: Development of Hybrids and their Seed Production in Vegetable Crops. Y.S.P. Univ. Hart. Forestry, Nauni, Solan. pp 46-47.

Kumar, S. and Singh, P. K. 2004. Mechanisms for Hybrid Development in Vegetables. Journal of New Seeds. 6(4): 300-407.

Kumar, S., Banerjee, M. K. and Kalloo, G. 2000. Male sterility: mechanisms and current status on identification, characterization and utilization in vegetables. Veg. Sci. 27: 1-24.

Kumar, S., Singh, V., Singh, M., Rai, S.K., Kumar, S., Rai, M. and Kalloo, G. 2007. Genetics and distribution of fertility restoration associated RAPD markers in pepper (Capsicum annuum L.). Hort. Sci., 111: 197202.

Lal, T., Vashisht, V. and Dhillon, N.P.S. 2007. Punjab Anmol - A new hybrid of muskmelon
(Cucumis meloL.). J. Res. Punjab agric. Univ., 44: 83

Lecouviour M, Pitrat Mand Risser GA. 1990. Fifth gene for male sterility in Cucumis melo. Cucurbits Genet. Coop. Rep. 13: 34.

Liu, W.Y. and Gniffke, P.A. 2004. Stability of AVRDC's cytoplasmic male sterile (CMS) pepper lines grown under low temperatures. Capsicum and Eggplant Newsletter, 23: 85-88.

Mariani C, De Beuckeleer M, Truettner J, Leemans J and Goldberg RB (1990). Induction of male sterility in plant by a chimaeric ribonuclease gene. Nature 347: 737-741.

Mariani C, Gossele V, De Beuckeleer M, De Block M, Goldberg RB, De Greef W and Leemans J (1992). A chimeric ribonucleaseinhibitor gene restores fertility to male sterile plants. Nature 357: 384-387.

McCreight, J.D. and Elmstrom, G.W. 1984. A third male sterile gene in muskmelon. Horticulture Science 19: 268-270.

McRae, D.H. 1985. Advances in chemical hybridization. Plant Breed. Rev. 3: 169-191.

Mohr, H. C., Blackhurst, H. T. and Jensen, E. R. 1955. Fl hybrid water-melon from open pollinated seed by use of a genetic marker. Proc. Amer. Soc; hart. Sci. 65: 399-404.

Moore, R.H. 1950. Several effects of maleic hydrazide on plants. Science 112: 52-53.

Morelock, T.E. 1974. Influence of cytoplasm source on the expression of male sterility in carrot, D. carota. Ph.D. Thesis. Wisconsin University.

Nandpuri, K.S., Singh, S. and Lal, T. 1982. 'Punjab Hybrid' a variety of muskmelon. Prog. Fmg., 18: 3-4.

Naylor, A.W. 1950. Observations on effects of maleic hydrazide on flowering of tobacco, maize and coclebut. Proc. Natl. Acad. Sci. 36: 230-232.

Nieuwhof, M. 1961. Male sterility in some cole crops. Euphytica 10: 351-356.

Nieuwhof, M. 1968b. Effect of temperature on the expression of male sterility in Brussels sprouts (Brassica oleracea L. var. gemmifera DC.). Euphytica 17: 265-273.

North C., Priestley W. G. 1962. A glossy-leaved mutant of Brussels sprout. Hort. Res. 1:95-99.

Nothnagel T., 1992: Results in the development of alloplasmic carrots \{Daucus carota.sativus Hoffm.). Plant Breeding 109:67-7. 
Ogura, H. 1968. Studies on the new male-sterility in Japanese radish with special reference to the utilisation of this sterility towards the practical raising of hybrid seed. Mem. Fac. Agric. Kagoshina Univ. 6: 39.

Patel, J.A., Shukla, M.R., Doshi, K.M., Patel, S.A., Patel, B.R., Patel, S.B. and Patel, A.O. 1998. Identification and development of male sterile in chilli (Capsicum annuum L). Vegetable Science 25: 145-148.

Pathak, C.S. and Gowda, R.V. 1994. Breeding for the development of onion hybrids in India: Problems and Prospects. Acta hortic. 358, 239242.

Pelletier, G., Ferault, M., Lancelin, D., Boulidard, L., Dore, C., Bonhomme, S., Grelon, M. and Budar, F. 1995. Engineering of cytoplasmic male sterility in vegetables by protoplast fusion. Acta Horticulturae 392: 11-17.

Pilrat, M. 1990. Gene list for Cucumis melo. L. Cucurbit \& Genet. Coop. Rep. 13: 58.

Pitchaimuthu, M., Dutta, O.P. and Swamy, K.R.M. 2012. Studies on inheritance of Geneic Male Sterility (GMS) and hybrid seed production in okra [Abelmoschus esculentus (L.) Moench.] J. Hortl. Sci. 7(2):199-202.

Rick, C. M. 1948. Genetics and development of nine malesterile tomato mutants. Hilgardia 18: 599-633.

Rundfeldt, H. 1961. Untersuchungen zur zuchtung des kopfkohhs (B. oleracea var capitata). Z P flanzenzucht 44: 30-62.

Sampson, D. R. 1966. Linkage of genetic male sterility with a seedling marker and its use in producing F1 hybrid seed of Brassica oleracea (cabbage, broccoli, kale etc.). Can. J. Plant Sci. 46: 703.

Sawhney, V.K. 1983. Temperature control of male sterility in a tomato mutant. J. Hered. 74: 51-54.

Shifriss, C. 1997. Male sterility in pepper
(Capsicum annuum L). Euphytica 93: 83-88.

Singh, J. and Kaur, S. 1986. Present status of hot pepper breeding of for multiple disease resistance in Punjab. Proceeding of VI EUCARPIA Meeting on Genetic and Breeding on Capsicum and Eggplant, held at Zaragoza (Spain), Oct 21-24 (1986): 111-114.

Soressi, G.P. and Salamini, F. 1975. A monomendelian gene inducing parthenocarpic fruits. Rep. Tomato Genet. Coop. 25: 22.

Swarup, V. and Gill, H. S. 1964. The use of marker gene in hybrid seed production in cabbage. Curro Sci. 33 (10): 315.

Tanksley, S.D., Rick. C.M. and Vallejos, C.E. 1994. Tight linkage between a nuclear male sterile locus and an enzyme marker in tomato. Theor. Appl. Genet. 68: 109-113.

Thompson, D.J. 1961. Studies of the inheritance of male sterility in the carrot, Daucus carota var. sativa. Proc. Amer. Soc. Hort. Sci. 78: 332-338.

Watts, V.M. 1967. Development of disease resistance and seed production in watermelon stocks carrying msg gene. J. Amer. Soc. Hort. Sci., 91: 579-580.

Welch, J.E. and Grimball, E.L. 1947. Male sterility in the carrot. Science 106: 594

Whitaker, TW. and Davis, G.N. 1962. Cucurbits: Botany, Cultivation and Utilization. World Crop Books, Leonard Hill Ltd., London.

Williams, M. E., Lecmans, J. and Michiels, F. 1997. Male sterility through recombinant DNA technology. In: Shivanna KR and Sawhney VK (eds), Pollen Biotechnology for Crop Production and Improvement. Cambridge Univ. Press, pp. 237-257.

Zhang, X.P., Rhodes, B.B., Baird, W.V., Skorupska, H.T. and Bridges, W.C. 1996. Development of genic male sterile watermelon lines with delayed-green seedling marker. HortScience 31: 123-126.

\section{How to cite this article:}

Sunidhi Mishra and Versha Kumari. 2018. A review on Male Sterility-Concepts and Utilization in Vegetable Crops. Int.J.Curr.Microbiol.App.Sci. 7(02): 3016-3034.

doi: https://doi.org/10.20546/ijcmas.2018.702.367 